culty of getting into practice increases too, and educated men have the mortification of seeing their advantages enjoyed by prescribing druggists and impudent charlatans. The Society think that if their Petition were granted, an immediate benefit would be conferred on the profession and the public, while it would not at all interfere with any future improvement.

Having thus, as I hope, satisfied you as to our liberality of feeling upon this subject, the Society desire me to return their acknowledgments for the very gratifying and zealous manner in which the attention of the British Medical Association has been directed to their efforts. They earnestly hope that the Association will add their powerful influence in aid of the common cause. Their sole object in thus petitioning the Legislature is to have the practice of an honourable profession confined to men of education and eompetent skill, whether that education and skill have been acquired at one end of the kingdom or the other. With the warmest hopes that your exertions in the cause of science and justice will neither relax nor lose their reward, I have the honour to be, Sir, yours most respectfully, for the Leeds Medical Society,

Leeds, March 2, 1838. George Wrilson. George Webster, Esq., M.D., Dulwich.

\section{LIFE ASSURANCE CERTIFICATES.}

REPLY OF MR. ROWE TO MIR. SMITH.

\section{To the Editor of THe LANCET.}

Sir :-Allow me once more to trespass briefly upon your valuable columns, and reply to Mr. Smith's allusions to one of $\mathrm{my}$ letters on the remuneration of medical men for filling up the reference-letters from assurance companies. In the first place, I wish to premise that though my feelings, in this iustance, are inimical to his, I write in the spirit of friendliness and good humour, and apply my remarks collectively to the whole profession, more than individually to him. The office to which I belong (the Mutual) is founded upon the only true and equitable principle to persons assuring their lives; its object is economy for the benefit of the assured, whose families receive an equal division of proits up to the day of their decease, therefore if a fee is saved, it is saved to the members generally, and not to proprietors, as is the case in offices founded upon proprietary principles.

BIr. Smith appears to have forgotten that all insurance societies appoint and pay their own medical officers in town and country; and therefore surely it is not just that they should remunerate both parties, though I have no doubt that the fee in every instance, if paid by the office, would eventually be reimbursed by the assured. I am certain
Mr. Smith would not give an opinion, which to the best of his belief, is not based upon just and honourable grounds; and therefore, in this instance $I$ infer that his judgment has been swayed by his colleague, and by the determination of his directors, to pursue a different line of conduct from the directors of other institutions. I cannot help thinking that the fruit of their experience will be loss and disappointment, as they will have many bad proposals for the sake of the fee, and of course the directors will remunerate the friend referred to as well as the doctor. Mr. Smith's interrogation whether $I$ attend those patients gratuitously in 1838, who paid me in 1837 , does not apply to the point, inasmuch as there is a wide difference between one act of disinterested kindness, and devoting oneself for one year to unrequited toil and labour.

Candidly speaking, here, and here only, rests the ground of my objection. I am proud of being one representative of a noble profession, proud of the tie of friendship which exists between myself and my patients, and I consider it inconsistent with this tie, and derogatory to our high character to squabble about a few pounds, which would enrich our pockets by detracting from our good name. Our anxieties and our labours have a claim upon the public, beyond the mere recompense of pounds and pence, and let us retain their best feeling, and our own mental respect, by upholding our independence and our liberality. I am, Sir, your obedient servant,

24, Woburn-place, March 21, 1838.

Matthias Rowe.

\section{ASSURANCE-OFFICE FEES.}

\section{To the Editor of THE LANCET.}

SIR:-I quite agree with your correspon. dent, Mr. E. Smith, that medical men ought to be remunerated on giving an opinion upon the insurance of a life; and to meet $\mathrm{Mr}$. Rowe's objection of fraud by the connivance of a medical man (a very improbable case), I would suggest that if the insurance is effected, the office ought to pay;-if not, the party seeking to insure his life. I have the honour to be, \&c.

March 20, 1838.

Justitia.

\section{DRUGGISTS PRACTISING MEDICINE.}

THE druggists of Halifax have published a "Reply" to the petition from 41 medical practitioners of that town, recently presented to the House of Commons, praying that druggists may be rendered liable, by law, to be summoned before magistrates for prescribing and practising medicine. The druggists (ten of whom have signed the "Reply"), denounce what they call the 